\title{
ANALISIS PEMILIHAN MEDIA PROMOSI PADA PERUSAHAAN JASA
} TERAPI

\section{Stefani}

Email: stepz_one@yahoo.com

\section{Penulis}

Stefani adalah staf pengajar di Universitas Tarumanagara dengan bidang peminatan pada rumpun kuantitatif, pemasaran, sumber daya manusia.

\begin{abstract}
One of the most important elements for the company is to introduce their products (services) to prospective customers. Hypnosis For Healing is a company engaged in services. One key to the success of this company especially to attract clients is through the promotion of this company so that it is known by many more people. It requires the selection of appropriate media in accordance with the consideration of criteria such as low cost, wide coverage. These service companies require appropriate promotional media. This study aims to find a suitable promotional media on HFH company. The research was conducted in the end of 2010. The analytical tool used is Analytical Ivarious alternatives based on several criteria. The results of this study show that the internet is a major media as a promotional tool to introduce to the general public.
\end{abstract}

\section{Key Words}

Methods of Analytical Hierarchy Process (AHP), Promotional media.

\section{PENDAHULUAN}

Dalam menghadapi tantangan global sekarang ini, banyak orang yang merasa usaha atau apa yang dikerjakannya kurang memuaskan karena meningkatnya persaingan satu sama lain. Oleh karena itu setiap orang berusaha semampu mungkin untuk 
mendapatkan hal yang terbaik, tetapi dalam melakukan hal tersebut tidak mudah karena kondisi setiap orang berbeda-beda antara individu yang satu dengan individu yang lainnya. Kondisi individu setiap orang dapat dipengaruhi oleh faktor eksternal dan faktor internal seseorang. Faktor eksternal seperti keluarga, teman, dan lingkungan sekitarnya, sedangkan faktor internal seperti dari dalam dirinya sendiri (Morissan, 2010:159).

Faktor eksternal kadang menjadi salah satu faktor yang dapat membuat kondisi seorang individu menjadi semangat (mendapat dukungan) dalam mengerjakan sesuatu atau sebaliknya menjadi malas (tidak semangat) dalam mengerjakan suatu pekerjaan. Sedangkan faktor internal seperti tidak adanya motivasi untuk mengerjakan suatu pekerjaan atau tidak adanya kemauan untuk maju, tidak (kurang) percaya diri dengan apa yang telah dikerjakan, adanya hambatan bakat, dan lain-lain. Faktor ekternal dan faktor internal saling mempengaruhi satu sama lainnya. Ada individu yang tetap dapat meraih apa yang diinginkan (sukses) walaupun faktor eksternalnya tidak mendukung, tetapi ada pula seseorang yang menjadi malas dan tidak mempunyai semangat untuk melakukan sesuatu karena menganggap dirinya tidak mampu melakukan hal-hal dengan baik. Oleh karena itu individu yang seperti itu kadang kala membutuhkan seseorang atau tempat untuk bertukar pikiran, karena individu tersebut menjadi tidak konsentrasi dalam mengerjakan sesuatu, yang pada akhirnya menyebabkan tidak tercapainya kepuasan dalam mengerjakan sesuatu.

Terdapat dokter-dokter ahli, psikiater, psikolog yang dapat membantu memecahkan masalah individu tersebut tetapi ada sebagian orang yang berpendapat mereka tidak menderita penyakit sehingga tidak memerlukan berobat ke dokter. Kadang kala mereka lebih memilih menyendiri merenungi nasib atau mencari seseorang yang dapat mendengarkan masalah mereka. Hypnosis For Healing (HFH) merupakan salah satu tempat yang dapat membantu seorang individu melepaskan masalah melalui pikiran mereka yang dapat mengganggu aktivitas mereka sehari-hari sehingga mereka dapat kembali beraktivitas dengan kegiatan sehari-hari mereka dengan beban pikiran yang sudah mulai kembali seperti semula (tidak tertekan dengan masalah-masalah yang ada). Tetapi ada beberapa orang yang berpendapat bahwa terapi ini sama dengan yang mereka saksikan di televisi atau di panggung secara langsung, sehingga mereka sering salah dengan persepsi mereka sendiri yang berakibat mereka tidak mempercayai dengan hal 
tersebut, mereka mempunyai pandangan yang salah. Oleh karena itu, strategi marketing mix merupakan strategi andalan dalam memasarkan suatu produk, tentunya setiap perusahaan ingin jasanya dikenal secara luas oleh konsumen. Selain itu, diharapkan pula konsumen yang menggunakan jasa ini merasa puas dan enggan beralih ke tempat terapi lainnya. Promosi adalah salah satu media yang digunakan dalam HFH. Berdasarkan hal tersebut di atas, maka penulis memilih topik penelitian dengan judul "Analisis Pemilihan Media Promosi Pada Perusahaan Jasa Terapi”.

\section{TUJUAN PENELITIAN}

Adapun tujuan dari penelitian ini adalah untuk mengetahui jenis media yang paling tepat digunakan untuk mempromosikan keberadaan dan manfaat jasa Hypnosis For Healing ini.

\section{TINJAUAN PUSTAKA}

\section{Pemasaran}

Dalam mencapai tujuan perusahaan, diperlukan suatu manajemen pemasaran yang baik. Manajemen pemasaran menurut Kotler dan Keller (2008:249):

"The art and science of choosing target markets and getting, keeping and growing customers through creating, delivering and communicating superior customer value."

Daridefinisi tersebut, dapat dikatakan bahwa perusahaan harus menciptakan suatu barang atau jasa sesuai dengan target pasar yang dituju. Selain itu, produk atau jasa harus terus melakukan inovasi dan dikomunikasikan kepada konsumen sehingga dapat tercapai tujuan perusahaan.

\section{Bauran Pemasaran}

Menurut Philip Kotler (2005:62), pengertian bauran pemasaran adalah bauran pemasaran adalah kumpulan alat pemasaran taktis terkendali dalam produk, harga, tempat, dan promosi yang dipadukan perusahaan untuk menghasilkan respons yang diinginkannya di pasar sasaran. Bauran pemasaran merupakan suatu variabel yang dapat digunakan oleh perusahaan sebagai alat untuk memenuhi keinginan pelanggan serta 
merupakan konsep dalam sistem pemasaran . Dalam pelaksanaannya dibutuhkan suatu strategi pemsaran yang dapat diterapkan untuk memuaskan konsumennya adalah dengan mengembangkan bauran pemasaran atau diistilahkan "Marketing influcences on consumer behaviour", dimana strategi pemasaran dilakukan untuk mempengaruhi proses pembuatan keputusan konsumen dan proses transaksi (Peter,2001). Bauran pemasaran merupakan suatu strategi di dalam pemasaran yang lebih dikenal dengan 4P, terdiri atas 4 elemen yang saling menunjang satu sama lain. Elemen-elemen yang terdapat di dalam marketing mix antara lain:

a. Produk : Kombinasi barang atau produk jasa yang ditawarkan perusahaan kepada pasar sasaran.

b. Harga : Jumlah uang yang harus dibayarkan pelanggan untuk memperoleh produk, sebagai nilai tukar.

c. Tempat : Meliputi kegiatan perusahaan yang membuat produk tersedia bagi pelanggan sasaran.

d. Promosi : Aktivitas yang menyampaikan manfaat produk dan membujuk pelanggan membelinya. Adapun alat-alat yang dapat digunakan oleh perusahaan untuk melakukan kegiatan promosi adalah:

1) Periklanan.

2) Promosi penjualan.

3) Hubungan masyarakat (publisitas).

4) Penjualan personel.

5) Pemasaran langsung.

Kelima hal diatas dikenal dengan istilah bauran promosi atau bauran komunikasi pemasaran. Dalam mencapai, meningkatkan, dan menjaga keuntungan perusahaaan, diperlukan cara-cara baru dalam mengantisipasi kebutuhan konsumen. Dengan terjadinya peningkatan penggunaan internet, bergeraklah status alat bauran promosi pemasaran langsung menjadi penting. Karena permintaan dan kebutuhan konsumen terhadap pemasaran langsung meningkat dengan sendirinya, sehubungan dengan meningkatnya penggunaan internet. Hubungan konsumen yang tadinya terjalin dengan cara surat 
menyurat tradisional, e-mail, dan telepon (hunting) sekarang dapat terjalin dengan lebih mudah berkat adanya internet dan perangkat situsnya.

\section{Promosi}

Kotler dan Amstrong (2006) menyatakan bahwa promosi merupakan suatu bentuk komunikasi pemasaran untuk menyebarkan informasi, mempengaruhi, dan mengingatkan konsumen terhadap suatu produk atau jasa yang ditawarkan agar konsumen ingin membeli dan loyal. Sedangkan Assauri (2009:272), mendefinisikan promosi sebagai :

"Cara untuk mempromosikan barang, jasa atau gagasan/ ide yang di biayai oleh sponsor yang dikenal, dalam rangka untuk menarik calon konsumen guna melakukan pembelian, sehingga dapat meningkatkan penjualan produk dari perusahaan yang bersangkutan."

Ketenaran suatu merk dapat dipertahankan atau bahkan ditingkatkan apabila perusahaan menggunakan suatu bentuk promosi yang tepat. Menurut Shimp (2003) beberapa fungsi periklanan yaitu:

1) Informing (memberi informasi)

Iklan yang menunjukkan kepada konsumen mengenai suatu merk dalam hal fitur, manfaat, meningkatkan jumlah permintaan, dan sebagainya.

2) Persuading (mempersuasi)

Iklan digunakan untuk membujuk konsumen agar mencoba menggunakan produk yang diiklankan.

3)Remainding ( mengingatkan)

Iklan digunakan untuk selalu mengingatkan konsumen terhadap suatu merk yang telah ada.

4)Adding value ( memberikan nilai tambah)

Perusahaan memberi penawaran untuk memberikan nilai tambah terhadap suatu produk seperti inovasi, penyempurnaan kualitas, dan mengubah persepsi konsumen.

5) Assisting (mendampingi)

Iklan hanya digunakan sebagai komunikasi dalam membantu promosi penjualan dengan kupon atau undian. 


\section{Bauran promosi}

Komunikasi dan promosi perlu dilakukan oleh perusahaan agar konsumen mengetahui keberadaan produk (jasa) dan menjamin agar mereka selalu meningkatnya produk (jasa) tersebut. Program promosi dan komunikasi biasanya dilakukan dengan melaksanakan kombinasi dari penggunaan iklan, personal selling, promosi penjualan dan public relation. Kombinasi tersebut dikenal dengan bauran promosi (promotion mix).

Assael (1993:552), menjelaskan bauran promosi / promotion mix adalah

"A promotional mix is the combination of communication strategies that a company uses to convey brand benefits to customers and influence them to buy".

Definisi bauran promosi diatas adalah kombinasi dari strategi komunikasi yang perusahaan lakukan untuk menyalurkan produknya ke konsumen dan mempengaruhi konsumen untuk membelinya.

Elemen-elemen promosi atau yang dikenal sebagai bauran promosi yaitu

1. Periklanan (Advertising)

Menurut Kotler dan Keller (2008:538-539), periklanan adalah

"Suatu bentuk presentasi dan promosi non personal dari berbagai ide, barang-barang atau jasa dari suatu perusahaan.”

Tujuan periklanan adalah suatu tugas komunikasi yang spesifik dan merupakan suatu tingkatan pencapaian yang harus diraih dengan target yang khusus dalam suatu waktu tertentu.

Media yang digunakan untuk menyampaikan pesan periklanan dapat ditempuh melalui sarana antara lain majalah, surat kabar, radio, televisi, papan reklame, spanduk, dan lain-lain.

Menurut Kotler dan Keller (2006:547) ada beberapa keuntungan dan batasan dari media yang digunakan untuk menyampaikan pesan periklanan yaitu sebagai berikut:

\section{1) Surat Kabar ( Newspaper)}

- Keunggulan : fleksibilitas, tidak terhambat waktu, jangkauan pasar lokal yang bagus, penerimaan secara luas, kepercayaan yang tinggi.

- Kelemahan : cepat usai, kualitas reproduksi yang lemah.

2) Televisi ( Televison) 
- Keunggulan : Kombinasi warna, suara dan gerakan, penarik perasaan, perhatian yang tinggi, pencapian tinggi.

- Kelemahan : Biaya yang mutlak mahal, cepat berlalu, penonton yang memilih lebih sedikit.

3) Surat pos ( Direct Mail)

- Keunggulan: Pemilihan calon konsumen, fleksibel, tidak ada kompetensi iklan dengan media yang sama, personalisasi.

- Kelemahan : Secara relatif mahal, terkesan surat sampah (junk mail).

4) Radio ( Radio)

- Keunggulan : Pengguna massa, selektivitas demografi dan geografi yang tinggi, biaya rendah.

- Kelemahan : Hanya dapat digambarkan secara audio, penarik perhatian yang lebih sedikit daripada penonton televisi, tingkat struktur yang tidak distandarisasi.

5) Majalah (Magazines)

- Keunggulan : Selektivitas demografi dan geografi yang tinggi, kredibilitas dan prestise, kualitas reproduksi yang tinggi, jangka panjang, pembaca yang berlanjut.

- Kelemahan : Beberapa sirkulasi sia-sia, posisinya tidak bisa dijamin.

6) Outdoor (Outdoor)

- Keunggulan : Fleksibel, ekpos yang tinggi dan berulang, biaya rendah, kompetisi yang rendah.

- Kelemahan : Selektivitas penonton terbatas, kreativitas terbatas.

7) Yellow pages ( Yellow Pages)

- Keunggulan : Jangkauan lokal yang bagus, kepercayaan tinggi, pencapaian luas, biaya rendah.

- Kelemahan : Kompetensi tinggi, kreativitas terbatas.

8) Newsletters

- Keunggulan : Selektivitas yang tinggi, kontrol yang penuh, kesempatan interaktif, biaya yang relatif rendah.

- Kelemahan : Biaya lebih melebihi yang direncanakan.

9) Brosur (Brochures) 
- Keunggulan : Fleksibel, dapat mendramatisasi pesan.

- Kelemahan : Kelebihan produksi dapat menyebabkan biaya melonjak.

10) Telepon ( Telephone)

- Keunggulan : Pengguna banyak, kesempatan memberikan sentuhan secara pribadi.

- Kelemahan : Biaya relatif mahal kecuali ada sukarelawan.

11) Internet ( Internet)

- Keunggulan : Selektivitas tinggi, kemungkinan interaktif, biaya relatif murah.

- Kelemahan : Penggunanya relatif dalam jumlah kecil di beberapa negara.

2. Penjualan Langsung ( Direct Marketing)

Penjualan langsung adalah sistem penjualan interaktif yang menggunakan satu atau lebih media iklan untuk menghasilkan tanggapan atau atau transaksi yang dapat diukur pada satu lokasi (Kotler, 2000:346). Penjualan langsung adalah penjualan dengan menggunakan surat, telepon, faksimile, e-mail dan alat penghubung non personal lain untuk komunikasi secara langsung dengan atau mendapatkan tanggapan langsung dari pelanggan dan calon pelanggan tertentu.

3. Internet Marketing

Dengan kemajuan teknologi komunikasi yang memungkinkan dilakukannya komunikasi yang interaktif melalui internet selain menggunakan media-media yang lain, khususnya melalui fasilitas yang dikenal dengan world wide web (www). Melalui media ini memungkinkan terjadinya arus informasi timbal balik yang memungkinkan pengguna dapat berpartisipasi dan memodifikasi bentuk dan isi informasi pada saat itu juga (real time). Dapat dikatakan internet (Morissan,2010:24) merupakan media yang bahkan dapat digunakan untuk melaksanakan seluruh elemen bauran promosi. Selain itu digunakan untuk beriklan, promosi penjualan dengan kupon, kontes dan undian secara online. Kadangkala internet digunakan untuk melakukan pemasaran langsung, penjualan personal, serta kegiatan hubungan masyarakat secara lebih efektif dan efisien.

4. Promosi Penjualan

Promosi penjualan dimaksudkan untuk memperkuat tanggapan konsumen. Beberapa media masa tidak akan seobjektif iklan, kebanyakan harus melakukannya 
dengan kesadaran dan sikap, secara objektif promosi penjualan adalah perilaku terorientasi. Promosi penjualan konsumen didesain untuk melakukan satu atau lebih sebagai berikut menurut Duncan (2007: 467):

1. Meningkatkan percobaan dan pembelian kembali.

2. Meningkatkan frekuensi dan kuantitas dari pembelian.

1. Penawaran uang iuran yang kompetitif.

2. Mengolah data-data pelanggan dan tingkat retensi pelanggan.

3. Penjualan silang dan memperluas penggunaan dari satu merek.

4. Memperkuat brand image dan memperkuat brand relationship.

5. Publisitas (Publicity)

Publisitas merupakan cara yang biasa yang digunakan oleh perusahaan untuk mempengaruhi konsumen secara tidak langsung agar mereka menyenangi produk dan perusahaan yang memasarkannya.

Publisitas menurut Kotler (2002) adalah:

"Non personal stimulation of demand for a product, service, or business unit by planning significant news about it in a published medium or it upon radio, television, or stage that is not paid for a sponsor"

Adapun yang termasuk dalam publisitas itu adalah seluruh informasi yang menyangkut barang atau organisasi yang disebarluaskan ke masyarakat dengan membuat berita komersial di media massa yang tidak dibayar oleh sponsor. Hal ini dilakukan dengan tujuan antara lain meningkatkan kesadaran konsumen akan barang dan jasa, mempertahankan/ memperbaiki citra perusahaan dan menghadirkan pesan yang dapat dipercaya.

6. Penjualan Perseorangan (Personal Selling)

Menurut Kotler (2003: 570) personal selling adalah

"An oral presentation in a conversation with one or more prospective purchase for the purchase for the purpose of marketing sales."

Dalam personal selling terdapat kontak secara langsung antara penjual dan pembeli, sehingga dapat menciptakan komunikasi dua arah pembeli dan penjual. Disamping menjelaskan dan memberitahukan tentang produk dan membujuk pembeli, personal selling juga menampung keluhan dan saran dari para pembeli sebagai umpan 
balik bagi perusahaan. Berbeda halnya dengan periklanan dan kegiatan promosi lainnya yang komunikasinya bersifat massa dan tidak bersifat pribadi, dalam operasi penjualan secara personal lebih fleksibel dibandingkan dengan yang lain. Hal ini disebabkan tenaga penjualan tersebut dapat mengetahui secara langsung keinginan, motif konsumen dan sekaligus dapat melihat reaksi konsumen. Dengan begitu mereka dapat langsung melakukan penyesuaian dengan reaksi tersebut

\section{Penentuan Sasaran (Tujuan) Promosi}

Penentuan jenis promosi yang digunakan setiap perusahaan berbeda-beda sesuai dengan kebutuhan perusahaan tersebut. Penentuan jenis promosi di Perusahaan HFH terbagi atas:

\section{a. Jangkauan}

Jangkauan (Reach), dalam Morrisan (2010:191), didefinisikan sebagai sejumlah audiens yang menyaksikan, mendengarkan atau membaca suatu media masa dalam periode waktu tertentu yang dinyatakan dalam suatu jumlah atau angka absolut atau sebagai suatu fraksi (bagian) dari populasi. Konsep jangkauan telah digunakan secara luas sebagai salah satu alat ukur dalam perencanaan media karena jangkauan dianggap sebagai suatu indikasi adanya peluang untuk menerima pesan, tetapi jangkauan bukanlah suatu indikator untuk mengetahui berapa banyak calon konsumen (konsumen) yang terekspos oleh suatu iklan. Karena banyak perencanaan media mengusulkan untuk menggunakan lebih dari satu kendaraan media. Jangkauan terbagi atas:

1. Lokal

Jangkauan secara lokal dapat dilakukan melalui penyiaran radio dan televisi. Dimana terdapat Undang-Undang penyiaran dalam Morrisan (2010:237) menyatakan bahwa stasiun penyiaran lokal dapat didirikan di lokasi tertentu dalam wilayah negara Republik Indonesia dengan wilayah jangkauan siaran terbatas pada lokasi tertentu. Berarti syarat atau kriteria jangkauan secara lokal adalah lokasi sudah ditentukan dan jangkauan siaran terbatas.

2. Nasional 
Jangkauan secara nasional seperti radio atau televisi yang menyiarkan programnya ke sebagian besar wilayah negara dari hanya satu stasiun penyiaran saja. Dimana cara menyebarluaskan program siarannya melalui berbagai stasiun pemancar (stasiun relai) yang dibangun di berbagai daerah. Melalui jangkauan ini, pemasang iklan (perusahaan) dapat menyiarkan (menyebarkan) pesan iklannya ke hampir seluruh wilayah negara secara serentak. Pemasangan iklan (promosi) hanya berurusan dengan satu pihak saja yaitu stasiun radio (televisi).

3. Internasional

Jangkauan secara internasional menurut Morissan (2010:238) mencakup seluruh negara dan cakupannya sangat luas tanpa adanya batasan.

\section{b. Harga}

Pengertian harga menurut Philip Kotler and Gary Armstrong (2006), "Price is the amount of money charged for a product or service." Philip Kotler dan Gary Armstrong berpendapat bahwa dalam arti sempit, harga adalah jumlah uang yang dibebankan untuk produk atau jasa. Secara lebih luas, harga adalah jumlah dari semua nilai yang konsumen tukar untuk manfaat memiliki atau menggunakan produk atau jasa. Salah satu keputusan terpenting dalam perencanaan strategi media adalah harga (biaya). Keunggulan dari suatu strategi media ditentukan dari seberapa jauh strategi itu mampu menghasilkan iklan (promosi) yang bisa diterima oleh target konsumen dengan harga (biaya) serendah mungkin.

\section{c. Target Konsumen}

Menurut Philip Kotler (2009:230), pengertian konsumen adalah semua individu dan rumah tangga yang membeli atau memperoleh barang atau jasa untuk di konsumsi pribadi. Menurut Nasution (2005:85), konsumen pada umumnya adalah setiap orang yang mendapatkan barang atau jasa digunakan untuk tujuan tertentu. Setiap konsumen berusaha untuk memenuhi kebutuhan hidupnya dengan pemenuhan yang maksimal. Jumlah dan keanekaragaman barang yang dapat dipenuhi bergantung pada besar pendapatan (penghasilan).Tingkat kemakmuran dan kesejahteraan seseorang atau masyarakat bergantung pada tingkat konsumsi yang digunakan. 


\section{Alternatif Media}

\section{Internet}

Menurut Morissan (2010:317) adalah "A worldwide means of exchanging information and communicating through a series of interconnected computers." Dapat diartikan suatu metode yang mendunia untuk saling tukar menukar informasi dan berkomunikasi melalui komputer yang saling terkoneksi. Konsumen mengharapkan komunikasi dua arah dengan perusahaan dan semakin banyak perusahaan yang menganggap kegiatan ini sebagai bentuk pelayanan kepada konsumen. Konsumen menggunakan internet untuk mengajukan pertanyaan, melakukan pemesanan produk (membuat janji/ sesi), serta menyampaikan keluhan kepada perusahaan.

\section{Radio}

Media penyiaran radio memiliki ciri sebagai media dengan target audiensi yang tidak terlalu luas (sempit), dimana mereka yang memiliki minat terhadap program tertentu atau khusus. Menurut Belch dalam Morissan (2010:319), radio adalah " $a$ medium characterized by highly specialized programming appealing to verry narrow segments of the population." Iklan radio memiliki sifat yang sangat lokal sehingga menjadi salah satu media yang dapat digunakan perusahaan lokal sehingga menjadi salah satu media yang dapat digunakan perusahaan lokal untuk mempromosikan produknyaa (jasa).

\section{Media Cetak}

Dalam perencanaan media (media plan), majalah dan surat kabar memiliki posisi yang berbeda dibandingkan dengan media penyiaran. Hal ini disebabkan kedua media cetak tersebut memungkinkan pemasangan iklan untuk menyajikan informasi secara lebih detail. Media cetak tidak memiliki sifat yang terlalu intrusif dalam arti terlalu masuk dalam kehidupan audiensinya. Media cetak membutuhkan upaya dari pihak pembaca agar iklan yang disajikan mampu memberikan efek.

\section{KERANGKA PEMIKIRAN}

Dalam penelitian ini, penulis akan menganalisis mengenai kriteria, subkriteria dan alternatif yang sudah ditentukan 


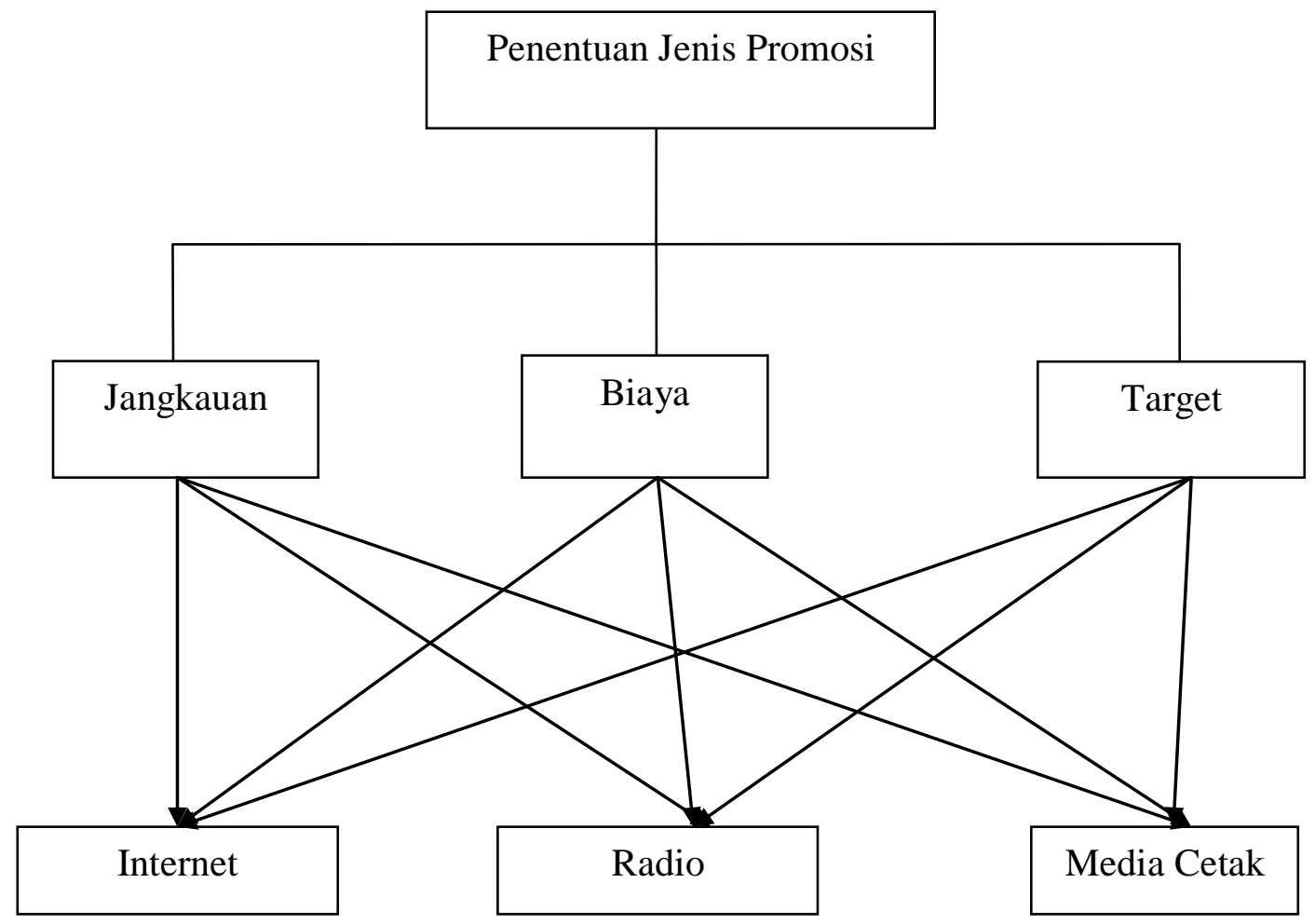

Sumber : diolah penulis

\section{METODOLOGI PENELITIAN}

Penulis memilih perusahaan jasa terapi Hypnosis For Healing sebagai subjek penelitian karena perusahaan ini menjadi pelopor dalam bidang terapi regresi ke kehidupan lalu di Jakarta. Oleh karena itu penulis tertarik untuk mengetahui media yang cocok untuk perusahaan ini.

Dalam mengumpulkan data, teknik pengumpulan data yang dilakukan penulis adalah sebagai berikut

a.Data primer

Data primer merupakan data yang belum tersedia sehingga harus dikumpulkan dari sumbernya seperti penyebaran kuesioner. Setiap butir pertanyaan di dalam kuesioner berhubungan dengan tujuan dalam penelitian.

b. Data sekunder

Data sekunder merupakan data yang telah ada sebelumnya. Penelitian ini memperoleh data dari buku bacaan atau literatur, internet, dan sumber lainnya yang berhubungan dengan tujuan penelitian. 
Setelah dilakukan pengumpulan data perusahaan, maka dilakukan pembandingan secara berpasangan, menghitung faktor pembobot, dan menganalisisnya untuk menghasilkan proritas relatif diantara alternatif yang ada dengan menggunakan metode Analytical Hierarchy Process (AHP). Langkah-langkah yang dilakukan adalah :

a. Menyusun secara hirarkis, yaitu memecah persoalan menjadi unsur-unsur yang terpisah.

b. Menetapkan prioritas yaitu menentukan peringkat elemen-elemen menurut relatif pentingnya.

c. Mengukur konsistensi logis yaitu menjamin bahwa semua elemen dikelompokkan secara logis dan diperingkatkan secara konsisten sesuai dengan kriteria yang logis.

Proses hirarki analisis dijabarkan lebih lanjut yaitu:

\section{Menyusun Hirarki}

Model secara hirarki yang terdiri dari beberapa tingkat rincian yaitu:

a. Hirarki tingkat tertinggi ialah fokus masalah, terdiri hanya atas satu elemen yaitu sasaran menyeluruh. Fokus masalah merupakan masalah utama yang perlu dicari solusinya.

b. Tingkat berikutnya adalah kriteria, merupakan aspek penting yang perlu dipertimbangkan dalam mengambil keputusan atas fokus masalah. Untuk suatu masalah yang kompleks atau berjenjang, kriteria dapat diturunkan kepada sub kriteria. Dengan demikian kriteria bisa terdiri lebih dari satu tingkat hirarki.

c. Tingkat terendah adalah alternatif, yang merupakan berbagai tindakan akhir atau rencana-rencana alternatif. Alternatif merupakan pilihan keputusan dari penyelesaian masalah yang dihadapi.

2. Menetapkan Prioritas

Setelah menyusun hirarki, perencana menetapkan hubungan elemen dari setiap tingkatan hirarki dengan membandingkan elemen-elemen itu secara berpasangan. Hubungannya menggambarkan pengaruh relatif elemen pada tingkat tertentu terhadap setiap elemen pada tingkat yang lebih tinggi.

Elemen pada tingkat yang tinggi tersebut berfungsi sebagai suatu kriteria dan disebut sifat (property). Hasil dari proses pembandingan ini adalah suatu 
prioritas, atau relatif pentingnya suatu elemen terhadap setiap sifat. Pembandingan berpasang diulangi lagi untuk semua elemen dalam tiap tingkat.

Untuk pembandingan berpasangan, matriks merupakan bentuk yang lebih disukai. Proses pembandingan dimulai dengan memilih suatu kriteria atau sifat, yang akan digunakan untuk melakukan pembandingan yang pertama. Selanjutnya dari tingkat tepat dibawahnya diambil elemen-elemen yang akan dibandingkan.

Tabel 1. Skala Banding Secara Berpasang

\begin{tabular}{|l|l|}
\hline Pendapat Numerik & Pendapat Verbal \\
\hline 1 & Kedua elemen sama pentingnya (equally preferred) \\
\hline 3 & $\begin{array}{l}\text { Elemen yang satu sedikit lebih penting ketimbang yang lainnya } \\
\text { (moderately preferred) }\end{array}$ \\
\hline 5 & $\begin{array}{l}\text { Elemen yang satu sangat penting ketimbang elemen yang lainnya } \\
\text { (strongly preferred) }\end{array}$ \\
\hline 7 & $\begin{array}{l}\text { Elemen yang satu jelas lebih penting dari elemen yang lainnya } \\
(\text { very strongly preferred) }\end{array}$ \\
\hline $2,4,6,8$ & $\begin{array}{l}\text { Elemen yang satu mutlak lebih penting ketimbang elemen lainnya } \\
(\text { extermely preferred) }\end{array}$ \\
\hline
\end{tabular}

Untuk memperoleh perangkat prioritas menyeluruh bagi suatu persoalan keputusan, kita harus menyatukan pertimbangan yang dibuat dalam melakukan pembandingan berpasang yaitu melakukan suatu pembobotan dan penjumlahan untuk menghasilkan satu bilangan tunggal yang menunjukkan prioritas setiap elemen. Elemen dengan bobot tertinggi adalah alternatif / rencana yang patut dipertimbangkan paling serius untuk diambil tindakannya, mesti rencana yang lain tidaklah harus dikesampingkan sama sekali.

Sintesis dihasilkan dengan melakukan normalisasi matriks pembandingan dengan cara:

a. Buat setiap entri menjaadi nilai relatif terhadap entri yang lain dalam kolom yang sama. 
b. Hitung nilai rata-rata setiap baris, yang menunjukkan nilai prioritas relatif altenatif (baris) tersebut terhadap alternatif lainnya.

3. Mengukur Konsistensi Logis

Penetapan relasi antar objek atau antar pemikiran sedemikian sehingga koheren yaitu obyek-obyek atau pemikiran itu saling terkait dengan baik dan kaitan mereka menunjukkan konsistensi. Dimana konsistensi adalah pemberian nilai yang konsisten dalam melakukan pembandingan antar obyek.

Rasio konsistensi (consistency ratio, CR) menunjukkan sejauh mana analis konsisten dalam memberikan nilai pada matrix pembandingan. Nilai yang besar menunjukkan kurang konsisten, sebaliknya nilai CR yang rendah menunjukkan lebih konsisten. Secara umum, hasil analisis dianggap konsisten jika memiliki $\mathrm{CR} \leq 10 \%$. Jika nilai $\mathrm{CR}$ lebih besar dari $10 \%$, perlu dipertimbangkan untuk melakukan reevaluasi dalam penyusunan matriks pembandingan.

Tahapan dalam memperoleh nilai rasio konsentrasi sebagai berikut::

1. Hitung vektor konsistensi yaitu dengan:

a. Melakukan pembobotan pada setiap kolom matriks pembandingan dengan vektor prioritas terkait.

b. Membagi jumlah setiap baris dengan vektor prioritas untuk memperoleh vektor konsistensi.

2. Hitung nilai lamda yaitu merupakan rata-rata dari nilai vektor konsistensi.

3. Hitung indeks konsistensi (Consistency index, CI ).

$\mathrm{CI}=\frac{\propto-n}{n-1}$

Dimana $\mathrm{n}=$ jumlah relatif yang dibandingkan

4. Hitung rasio konsentrasi merupakan rasio antara rasio indeks konsistensi dengan indeks acak (random index, RI).

$$
\mathrm{CR}=\frac{C I}{R I}
$$

Indeks acak merupakan fungsi langsung dari n (jumlah alternatif atau sistem yang dipertimbangkan). 
Tabel 2. Tabel Indeks Acak

\begin{tabular}{|l|l|l|l|}
\hline $\mathrm{n}$ & RI & $\mathrm{n}$ & RI \\
\hline 2 & 0,00 & 6 & 1,24 \\
\hline 3 & 0,58 & 7 & 1,32 \\
\hline 4 & 0,90 & 8 & 1,41 \\
\hline 5 & 1,12 & & \\
\hline
\end{tabular}

\section{HASIL DAN ANALISIS DATA}

Hirarki dalam penelitian ini terdiri dari 3 tingkat hirarki yaitu:

- Tingkat 1 berisi tentang fokus yaitu menentukan media promosi yang tepat untuk digunakan dalam mempromosikan HFH.

- Tingkat 2 berisi tentang karakteristik dalam menentukan tujuan atau sasaran (tingkat 1). Dalam model ini terdapat 3 karakteristik yang dipertimbangkan yaitu jangkauan, biaya dan target konsumen. Yang dimaksud jangkauan adalah cakupan yang diberikan/ dimiliki oleh media tersebut dalam menjangkau konsumen. Biaya yang dimaksud adalah sejumlah uang (ongkos) yang dikeluarkan oleh perusahaan dalam mempromosikan menggunakan media tersebut. Biaya ini mencakup instalemen dan biaya langganan dalam taksiran waktu 1 tahun. Sedangkan target konsumen yang dimaksud adalah konsumen yang berlokasi di Jakarta serta berpendidikan, yang peduli dengan kesehatan, konsumen yang mempunyai tingkat sosial menengah ke atas, termasuk ibu-ibu rumah tangga yang berkepentingan untuk dirinya dan anaknya.

- Tingkat 3 berisi tentang pemilihan media yang akan digunakan. Dalam hal ini berbagai media yang ada hanya dipilih 3 media utama yaitu internet, media cetak dan radio. Ketiganya memiliki kelebihan dibandingkan berbagai media lain antara lain dalam hal jangkauan dan biaya.

\section{Pengelompokan prioritas intensitas sifat yang disenangi}

Dalam mengelompokkan prioritas intensitas sifat yang disenangi dalam kolomkolom dan masukkan prioritas yang dinormalisasi di atas kolom. 
Tabel 3. Persepsi Sifat Promosi (Jasa) Menyeluruh

\begin{tabular}{|l|l|l|l|}
\hline & 0,104 & 0,665 & 0,231 \\
\hline & Jangkauan & Harga & Target Konsumen \\
\hline Internet & 0,648 & 0,619 & 0,724 \\
\hline Radio & 0,230 & 0,096 & 0,083 \\
\hline Media Cetak & 0,122 & 0,284 & 0,193 \\
\hline
\end{tabular}

Dari hasil penelitian ini berdasarkan Analisis Hierarki Proses dapat ditarik kesimpulan bahwa media promosi yang dipelajari, internet karena memiliki peringkat tertinggi dengan nilai 0,646 disusul secara berturut-turut oleh media cetak dan radio dengan nilai 0,246 dan 0,107. Ini berarti internet dapat memperoleh jangkauan target konsumen yang paling baik untuk cakupan yang menjadi target di perkotaan dan harga yang murah.

Internet memiliki beberapa keunggulan dibandingkan dengan media lainnya seperti dapat membidik target konsumen yang spesifik (khusus), pelanggan atau calon pelanggan akan dapat dengan mudah menemukan lokasi usaha atau nomor telepon perusahaan, penyampaian informasi yang cepat dan praktis mengenai suatu produk, mengurangi jumlah tenaga dan melalui internet, perusahaan akan mendapatkan perhatian dari konsumen nasional bahkan internasional dalam waktu yang sangat cepat.

Tabel 4. Persepsi Sifat Promosi (Jasa) Secara Menyeluruh dan Terbobot

\begin{tabular}{|l|l|l|l|l|l|}
\hline & Jangkauan & Harga & $\begin{array}{l}\text { Target } \\
\text { Konsumen }\end{array}$ & Jumlah & Prioritas \\
\hline Internet & $\begin{array}{l}0,067 \\
(0,104 * 0,648)\end{array}$ & $\begin{array}{l}0,412 \\
(0,665 * 0,619)\end{array}$ & $\begin{array}{l}0,167 \\
(0,231 * 0,724)\end{array}$ & 0,646 & 1 \\
\hline Radio & $\begin{array}{l}0,024 \\
(0,104 * 0,230)\end{array}$ & $\begin{array}{l}0,064 \\
(0,665 * 0,096)\end{array}$ & $\begin{array}{l}0,019 \\
(0,231 * 0,083)\end{array}$ & 0,107 & 3 \\
\hline $\begin{array}{l}\text { Media } \\
\text { Cetak }\end{array}$ & $\begin{array}{l}0,013 \\
(0,104 * 0,122)\end{array}$ & $\begin{array}{l}0,189 \\
(0,665 * 0,284)\end{array}$ & $\begin{array}{l}0,045 \\
(0,231 * 0,193)\end{array}$ & 0,246 & 2 \\
\hline
\end{tabular}

Sintesis ini menghasilkan prioritas sebagai berikut: 
1. Internet mendapatkan peringkat (prioritas) yang pertama karena menghasilkan 0,646 dari hasil perhitungan.

2. Media cetak mendapatkan peringkat (prioritas) yang kedua karena menghasilkan 0,246 dari hasil perhitungan.

3. Radio mendapatkan peringkat (prioritas) yang ketiga karena menghasilkan 0,107 dari hasil perhitungan.

\section{KESIMPULAN DAN SARAN}

\section{Kesimpulan}

Dari hasil penelitian ini berdasarkan Analisis Hierarki Proses dapat ditarik kesimpulan bahwa media promosi yang dipelajari, internet karena memiliki peringkat tertinggi dengan nilai 0,646 disusul secara berturut-turut oleh media cetak dan radio dengan nilai 0,246 dan 0,107. Ini berarti internet dapat memperoleh jangkauan target konsumen yang paling baik untuk cakupan yang menjadi target di perkotaan dan harga yang murah.

Internet memiliki beberapa keunggulan dibandingkan dengan media lainnya seperti dapat membidik target konsumen yang spesifik (khusus), pelanggan atau calon pelanggan akan dapat dengan mudah menemukan lokasi usaha atau nomor telepon perusahaan, penyampaian informasi yang cepat dan praktis mengenai suatu produk, mengurangi jumlah tenaga dan melalui internet, perusahaan akan mendapatkan perhatian dari konsumen nasional bahkan internasional dalam waktu yang sangat cepat.

\section{Saran}

Adapun saran-saran yang dapat penulis berikan bagi perusahaan ini antara lain:

a. Perusahaan memutuskan pada promosi dengan menggunakan internet. Hal-hal yang dikembangkan antara lain:

- Dengan mengupdate iklan.

- Menyediakan adanya blog.

- Features yang lebih menarik.

b. Bagi para peneliti dapat melanjutkan analisis dengan menggunakan berbagai kriteria atau alternatif lain untuk kasus yang sejenis / berbeda. 


\section{DAFTAR PUSTAKA}

A, Shimp, Terence (2003). Periklanan Promosi \& Aspek Tambahan Komunikasi PemasaranTerpadu, Jilid I ( edisi 5), Jakarta Erlangga.

Arman Hakim Nasution, dkk. (2006). Manajemen Pemasaran Untuk Engineering. Yogyakarta: Andi

Assauri, Sofjan. (2009). Manajemen Pemasaran (Edisi 1). Jakarta: Rajagrafindo Persada.

Duncan, T., (2007). Principles of Advertising and IMC. The Mcgraw- Hill Companies.

Henry ,assael (1993). Consumer behaviour and marketing action: Singapura,

Thomson Learning.

Kottler, Philip. (2000). Marketing Management ( $9^{\text {th }}$ Ed.). New Jersey: Prentice Hall, Inc. ,(2002), Manajemen Pemasaran, Jilid 1, Edisi Milenium, Jakarta, Prehallindo. , (2005), Manajemen Pemasaran, Alih Bahasa: Hendra Teguh, Ronny A. Rusli dan Benyamin Molan, Jakarta: Prenhallindo.

Kotler, Philip \& Garry Amstrong. (2006). Principles of Marketing, 11th Edition. Pearson International Edition, New Jersey: Prentice Hall.

Kotler, Philip \&Kevin Lane Keller, (2006), Marketing Management, Pearson Education Inc.

Kotler, Philip (2008). Prinsip-Prinsip Pemasaran (Jilid 2). Edisi ke-12. Penerbit: Erlangga.

Kottler, Philip \& Kevin Lane Keller. (2008). Marketing Management. New Jersey: Pearson Education, Inc.

Kottler, Philip. (2009).Manajemen Pemasaran. Jakarta: Erlangga

Morissan, M.A. (2010). Komunikasi Pemasaran Terpadu. Jakarta: Kencana

Peter, J. Paul \& Donnelly, James H.Jr (2001), Marketing Management : Konwledge and Skills. New York : Mc Graw Hill International Edition 